\title{
Case law on standard essential patents in Europe
}

\author{
Enrico Bonadio ${ }^{1} \cdot$ Anushka Tanwar ${ }^{2}$
}

Accepted: 22 September 2021 / Published online: 5 October 2021

(c) The Author(s) 2021

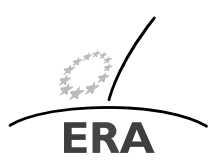

EUROPÄ|SCHE RECHTSAKADEMIE ACADEMY OF EUROPEAN LAW ACADEMIE DE DROIT EUROPEEN ACCADEMIA DI DIRITTO EUROPEO TRIER - TREVES - TREVIRI

\begin{abstract}
In Europe disputes over SEPs are frequently litigated. In Huawei v ZTE, the CJEU gave a landmark judgement where it established guidelines to balance the interests of SEP owners and those of implementers. In this paper we will cover that case as well as other important SEP-related decisions from courts in the UK, Germany, France, Netherland and Italy.
\end{abstract}

Keywords Standardisation · Patents $\cdot$ Enforcement $\cdot$ Competition

\section{Introduction}

Whether we realise it or not, citizens in Europe and other areas of the world make use of technological 'standards' every day. USB is a standard. MP3 is another. The 4G (and now 5G) communication technologies we use contain a host of standards. Without the use of standards there would be no interoperability between devices manufactured by different companies. Thus, standardisation enables efficiency gains that benefit consumers, by allowing manufacturers to increase the overall size of markets, achieving vast economies of scale as well as increased product substitutability. Standardisation is particularly crucial in the information and communication technology (ICT) and Internet of Things fields (IoT) (consumer electronics, automotive industry, and electricity grid industry).

$\triangle$ E. Bonadio

Enrico.Bonadio.1@ city.ac.uk

A. Tanwar

anushkadheertanwar@gmail.com

1 City, University of London, London, UK

2 University School of Law and Legal Studies, New Delhi, India 
On the other hand, patents are a type of property. As with any kind of property, owners must be able to enforce their rights against competitors who infringe upon their patents. Without the ability to enforce, there would be no way to recoup the investment in resources required to create a new patentable invention in the first place. Patents cover new inventions, including important technology standards. Patents on standards are commonly known as Standard-Essential Patents (SEPs) and are frequently litigated.

The existence of SEPs - and associated litigation - has potentially disruptive consequences for the manufacture, marketing and distribution of complex products that include many patented standards, e.g. ICT products such as smart-phones incorporating a camera, a video, a web browser, wireless, text messages, etc, as well as an increasing array of IoT 'networked' products such as wearable devices and appliances for 'smart homes'. By enforcing their patents - their time-limited monopoly rights - owners of SEPs could, if they wished, use the patent enforcement system to 'hold up' or prevent competitors from launching rival products that use the same standards. This raises serious concerns over competition in the marketplace and the need to maintain interoperability to ensure the IoT industry can develop. Therefore, tension exists between SEPs (which offer their owners R\&D incentives/rewards in the form of monopolistic rights) and standards (which allow for widespread and collective use).

How can an appropriate balance be reached? How can the optimum scenario of incentivising the development of new inventive technologies, including standards, while also allowing fair competition to be achieved? The answer is clear: fair licensing practices. In order to balance the need for standardisation, required for public use, with the private rights of SEP-holders, standard-setting organisations (SSOs) typically require SEP-owners to give an irrevocable undertaking that they are prepared to grant competitors licences on FRAND terms (fair, reasonable, and nondiscriminatory).

Difficulties arise however, when a consensus cannot be reached between the parties as to what FRAND is in a particular scenario. If SEP-owners and prospective licensees disagree over e.g. the value of the royalties that should be considered fair and reasonable, or if the parties disagree over the territorial scope of the licence, this could lead to inconvenient hold-up of technology diffusion and marketing of products and service.

Such difficulties, and lack of consensus between SEP owners and implementers, often turn into litigations. Disputes also occur in relation to issues other than FRAND, for example as regards to declaration of essentiality and the right of SEP holders to enforce an injunction. In this paper, we will exactly look at SEP litigations in Europe. More specifically, we will highlight the most recent and important cases from UK, Germany, France, Netherlands and Italy. Before examining disputes decided by British, German, French, Dutch and Italian judges, we analyse the approach followed by the Court of Justice of the European Union (CJEU) when it comes to SEPs. 


\section{CJEU}

\subsection{Huawei v. ZTE}

After Huawei and ZTE's FRAND negotiations failed, in 2011 Huawei brought an action for infringement and sought an injunction against ZTE before the Düsseldorf Regional Court. Huawei holds a SEP (EP 2090050 B 1) which covers the 4G "Long Term Evolution" (LTE). Huawei, a member of the European Telecommunications Standards Institute (ETSI), notified the patent to the institute and guaranteed to grant its licences to third parties on FRAND terms. ZTE marketed telecommunication products incorporating Huawei's LTE SEP in Germany and thus - according to Huawei - infringing its patent. ZTE claimed that Huawei was abusing its dominant position by seeking an injunction, since ZTE was willing to negotiate a licence. The Düsseldorf District Court requested for a preliminary ruling from the CJEU regarding which standard applies for finding a breach of Art. 102 of the Treaty for the Functioning of the European Union (TFEU) where injunctive reliefs are sought by SEP owners. Art. 102 TFEU prohibits abuse of dominant position in the EU.

In July 2015 the CJEU held that Art. 102 TFEU must be interpreted as meaning that the SEP proprietor, who has given an irrevocable commitment to a standardization body to grant a licence on FRAND terms to third parties, does not abuse its dominant position by seeking an injunction or recall the products which use its patent, ${ }^{2}$ as long the SEP proprietor alerts the alleged infringer of the violation and the infringing products; and after the alleged infringer agrees to conclude a licensing agreement on FRAND terms, the SEP proprietor must present a written offer for the same. Furthermore, the alleged infringer must respond diligently to the proprietor's offer in good faith, without any delaying tactics.

\subsection{Nokia v. Daimler ${ }^{3}$}

The case between Nokia and Daimler has focused on licences for patented technologies that are essential to standard for navigation, vehicle communications and selfdriving cars. ${ }^{4}$ In 2019, Nokia brought a legal action against carmaker Daimler, claiming patent infringement on the basis that Daimler was using its patented technology (EP 2087629 B1) without obtaining the required licence.

Various complaints were lodged with the European Commission by a variety of industry players against Nokia, claiming that Nokia had refused to issue licences for its patented technology on the principle of "fair economic conditions", meaning they believed Nokia was abusing its dominant position and violating EU competition rules by asking for licensing fees which are too high and unfair. Furthermore, Daimler claimed that Nokia was violating its commitment to license its SEP to third parties, as

\footnotetext{
${ }^{1}$ Case C-170/13 Huawei Technologies Co. Ltd v. ZTE Corp. and ZTE Deutschland GmbH [2015] EU:C:2015:477.

${ }^{2}$ Bharadwaj, Verma [1].

${ }^{3}$ Nokia v. Daimler, Decision of 26 November 2020, Regional Court of Düsseldorf, 4c O 17/19.

${ }^{4}$ Bonadio, McDonagh [2].
} 
Nokia was ready to issue a licence to Daimler, but not to its suppliers. Nokia argued that suppliers cannot be considered as having a right to the licence, adding further that they would just be able to access the technology. In 2020 the Düsseldorf Regional Court referred a set of questions to the CJEU. First, is it an abuse of a dominant position by a SEP holder if instead of granting a license to a supplier, it files a patent infringement suit asking for an injunction? Second, does the SEP holder have the authority to choose the company in the supply chain to bring a patent infringement action against in court? Third, can SEP owners choose to grant licences on FRAND terms to companies in the manufacturing chain $?^{5}$

In June 2021, both the parties reached a settlement and concluded a licence agreement for the use of Nokia's patent. The CJEU therefore will no longer decide on the questions posed by the Düsseldorf Regional Court. ${ }^{6}$

\section{United Kingdom}

\subsection{Unwired Planet V. Huawei - Conversant V. Huawei and ZTE ${ }^{7}$}

The Supreme Court of the United Kingdom addressed appeals resulting from two separate cases i.e., Unwired Planet $v$ Huawei and Conversant v Huawei and ZTE. In 2014, Unwired Planet filed a suit against Huawei, Samsung and Google before the High Court in London, claiming that they had infringed six of its patents, out of which five had been declared SEP. Both Samsung and Google reached settlements. In 2017, the High Court granted an injunction against Huawei, which appealed the decision. However, in 2018, the UK Court of Appeal dismissed the appeal. Huawei again appealed before the Supreme Court.

In Conversant v Huawei and ZTE, Conversant filed an infringement suit before the High Court against Huawei and ZTE in 2017. Conversant claimed that the defendants had infringed four of its SEPs and further asked the court to determine what licensing terms would be FRAND. In retaliation, both Huawei and ZTE challenged the jurisdiction of the courts of England and Wales, arguing that the Chinese courts were more suitable for the case. On 16 April 2018, the court affirmed its jurisdiction over the dispute, as well as its competence to determine the terms for a global FRAND licence to SEPs. Both Huawei and ZTE appealed the decision of the court - however, on 30 January 2019, their appeal was dismissed by the Court of Appeal. This led Huawei and ZTE to appeal before the UKSC.

The Supreme Court unanimously dismissed the appeal in both cases and held that the English courts do have the jurisdiction to determine the terms for a global FRAND licence.

\footnotetext{
${ }^{5}$ Bonadio, McDonagh [3].

${ }^{6} \mathrm{Klos}$ [4].

${ }^{7}$ Unwired Planet International Ltd and another v. Huawei Technologies (UK) Co Ltd and another [2018] UKSC 0214. 


\subsection{Optis v Apple 8}

This case arises from the contentions raised by the non-practising entity Optis, and its partners, PanOptis Patent Management and Unwired Planet LLC. Optis claimed that Apple's iPhones, which implement the LTE cellular standard, infringe upon their SEPs on $3 \mathrm{G}$ and $4 \mathrm{G}$. The case is multi-jurisdictional and was first litigated in favour of Optis in a Texan Court in August 2020, wherein it was found that Optis' patent rights had been "wilfully" infringed by Apple, with Optis being granted the relief of $\$ 506$ million. The Texas damage award was then reversed in April 2021 by US District Judge Rodney Gilstrap who emphasized the question of whether the royalty was consistent with FRAND terms, leading to a retrial (Optis Wireless Technology v. Apple Inc., 19-66, U.S. District Court for the Eastern District of Texas). On 13 August 2021, the federal jury awarded $\$ 300$ million to Optis and its affiliates in damages in the retrial against Apple.

Thereafter, in 2020, Optis took Apple to court in a UK lawsuit over the same SEPs. As the case stands, following the second in a series of four technical trials in June 2021, the High Court of London held that Apple infringed Optis' patent rights. It also stated that any decision the court makes on the FRAND royalty amount that the iPhone maker must pay would apply worldwide, not just to its UK sales (in line with the UK Supreme Court decision in Unwired Planet v Huawei). The High Court will also verify whether Apple's action renders it an 'unwilling licensee'.

Apple will be subject to another hearing in 2022 before the High Court which will determine the aforementioned level royalty rate to be paid to Optis globally. An essential aspect of this concerns whether Apple ought to be labelled an unwilling licensee. In UK law, the noncompliance with a court-determined FRAND royalty value is the key element that would make Apple an unwilling licensee; a finding which - the UK judicial argument goes - is consistent with the approach taken by the CJEU in Huawei v ZTE.

\subsection{TQ Delta v ZyXEL ${ }^{9}$}

In this case, TQ Delta started proceedings against ZyXEL before the High Court, claiming that ZyXEL had infringed its SEPs and therefore, sought an injunction against ZyXEL. These proceedings involved both technical issues regarding the validity, essentiality and infringement of the patents in suit (technical trial), as well as the licensing of these patents on reasonable and non-discriminatory terms (RAND trial). ZyXEL did not agree to obtain a licence on whatever terms the court determine to be RAND. ${ }^{10}$ In March 2019, in the technical trial, the court found that one of the patents was valid, essential and infringed, and the other patent was invalid. The patent that was found valid, essential and infringed expired in June 2019, i.e. three months prior to the RAND trial which was scheduled for September 2019. ${ }^{11} \mathrm{ZyXEL}$

\footnotetext{
${ }^{8}$ Optis Cellular Technology LLC \& Ors v Apple Retail UK and Ors. [2021] EWHC 131 (Pat).

${ }^{9}$ TQ Delta LLC v ZyXEL Communications UK Limited \& anr, [2019] EWCA Civ 1277.

$10_{\text {ibid, at para. } 10 .}$

$11_{\text {ibid, at para. } 2}$
} 
thought an injunction would be a better option than facing the risk of a RAND licence on global terms, hence it waived its right to such licence. The court granted the injunction. ZyXEL requested for a stay of the injunction, but the court refused. Furthermore, the court did not grant ZyXEL permission to appeal the injunction. ${ }^{12}$

TQ Delta, in order to keep its RAND claim active, sought declarations that ZyXEL were not willing licensees to its patents and that it was not under any obligation to offer ZyXEL any licence. TQ Delta insisted that the RAND trial was necessary since there was a live dispute between both the parties, however, ZyXEL requested to cancel the RAND trial on the basis that ZyXEL did not use RAND as a defence. In April 2019, Birss J agreed with TQ Delta regarding the live dispute between the parties as to RAND terms and therefore, allowed to move forward with the proceedings in September. ZyXEL appealed the decision. ${ }^{13}$ In July 2019 in the Court of Appeal, Floyd LJ pointed out the principles from the Court of Appeal's decision in Unwired Planet $v$ Huawei and called off the RAND trial. Further, he stated that the Unwired Planet $v$ Huawei decision did not suggest that a patentee had an independent right to pursue a declaration of the relevant licence terms when the implementer has no interest in obtaining the licence. ${ }^{14}$ In addition, he highlighted problems in TQ Delta's request for a declaration, i.e. that ZyXEL were not willing licensees; he found no evidence of any foreign proceedings between the parties regarding RAND. Moreover, Floyd LJ held that there is no unified approach to the interaction between the RAND undertaking and relief for patent infringement; and that the concept of a willing licensee is not an internationally recognized term of the art. He further noted that presence of other ZyXEL companies would also be required in the case in order to determine RAND globally. Furthermore, he pointed out that a RAND trial would take about 10 days with estimated cost of $£ 4$ million, which was not justified taking into account the court's limited resources. ${ }^{15}$ This resulted in cancellation of the RAND trial.

\subsection{Mitsubishi \& Sisvel v OnePlus, Oppo \& Xiaomi ${ }^{16}$}

A portfolio of patents for mobile telecommunications technologies referred to as the Mobile Communication Program or MCP is administered by Sisvel. Some of the patents are owned by Sisvel and others belong to various companies including Mitsubishi Electric Corporation. Mitsubishi and Sisvel tried to persuade the defendants as well as other implementers to obtain licences for the portfolio at conditions which they claimed to be FRAND. ${ }^{17}$ However, they were unsuccessful in doing so as the implementers refused to obtain licences on the basis that the patents were not essential to the standards and the offer provided by Mitsubishi and Sisvel - they argued - was not on FRAND terms. Mitsubishi and Sisvel filed a suit claiming that three

\footnotetext{
12 ibid, at para. 19.

${ }^{13}$ Heard, Morgan, Wong [5].

${ }^{14}$ Bristows [6].

${ }^{15}$ Sherliker [7].

${ }^{16}$ Mitsubishi \& Sisvel v OnePlus, Oppo \& Xiaomi [2021] EWHC 1541 (Pat).

${ }^{17}$ Raynor [8].
} 
patents in the portfolio (two owned by Mitsubishi and one by Sisvel) were infringed. Mitsubishi and Sisvel again offered to grant licences on FRAND terms if their infringement proceedings were successful. ${ }^{18}$ The court ordered separate trials to determine the essentiality and validity of the patents and whether the licensing terms were FRAND. ${ }^{19}$ In June 2021, the High Court in London (Mr Justice Mellor) held that the patents in suit were valid and essential to the LTE standard. Proceedings for determination of FRAND terms for licensing the MCP pool were set to be heard in October 2021.

\section{Germany}

\subsection{St Lawrence Communication v Deutsche Telekom ${ }^{20}$}

On 27 November 2015, the Mannheim Regional Court granted an injunction against Deutsche Telekom (DT) based on the infringement of European patent EP 1125 284 (Patent), owned by St Lawrence communication. The Patent was found to be essential for the AMR-WB standard relevant for wideband audio coding used in HDVoice transmission. DT sells mobile phones incorporating the patented technology owned by the plaintiff. DT purchases the mobile phones incorporating the standard from manufacturers (HTC, Huawei Technologies and Sony Mobile Communications) which also acted as interveners in the proceedings. St Lawrence made an offer to grant licences for its patent on FRAND terms to DT but not to the mobile phone manufacturers. However, DT declined the offer to enter into a licence agreement in order to use the patent, leading St Lawrence to seek an injunction against DT to prohibit it from using and selling mobile phones that were manufactured according to the patented standard. In its defence, DT doubted about the willingness of manufacturers to enter into a FRAND licence agreement. It referred to the CJEU's decision in Huawei $v$ ZTE, stating that a SEP owner which has given a commitment to a standardization body to grant licences on FRAND terms to third parties, must notify the alleged infringer in writing before seeking an injunction. The Mannheim Regional Court dismissed the FRAND defence since Deutsche Telekom were unwilling to conclude a global licence agreement. However, on appeal, the injunction was suspended; nevertheless, after Huawei v ZTE, the Manheim Regional Court granted the injunction, thus following the CJEU guidance.

\subsection{Sisvel v Haier $^{21}$}

Sisvel holds numerous SEPs for various mobile telecommunications standards. In 2013, Sisvel notified Haier about the infringement of one of its SEPs (EP 0852885

\footnotetext{
${ }^{18}$ Lambert [9].

19 ibid.

${ }^{20}$ St Lawrence Communication v. Deutsche Telekom, Mannheim District Court, 10 March 2015, 2 O 103/14; St Lawrence Communication v Deutsche Telekom, Karlsruhe Court of Appeal, 23 April 2015, 6 U 44/15; St Lawrence Communication v Deutsche Telekom, Mannheim District Court, 27 November 2015, 2 O 106/14, 2 O 107/14, 2 O 108/14.

${ }^{21}$ Sisvel v Haier, Düsseldorf District Court, 3 November 2015, 4a O 144/14 und 4a O 93/14; Sisvel v Haier, Düsseldorf Court of Appeal, 13 January 2016, 15 U 65/15 and 15 U 66/15.
} 
and EP 1264 504) by Haier. A year after receiving Sisvel's notice, Haier requested more information regarding royalties, expressing its interest in a possible licence. Sisvel made an offer which was rejected by Haier. Later, Haier made a counteroffer which Sisvel rejected. The parties failed to reach an agreement on a FRAND licence, leading Sisvel to file an infringement suit against Haier in the Düsseldorf Regional Court, seeking damages for Haier's use of its patents and an injunction against Haier's products incorporating its patented technology. Haier claimed that the licence fee demanded by Sisvel was unreasonable, and that they had only offered a worldwide licence, rather than a Germany specific one. The Düsseldorf Regional Court held that Sisvel's SEPs were indeed infringed by Haier. However, the Court of Appeal found that Sisvel had violated its FRAND obligations by granting discounts to an existing licensee (Hisense), while not offering the same benefits to Haier. Therefore, the Court of Appeal found Sisvel to abuse its dominant market position. In 2020, the German Supreme Federal Court overruled the Court of Appeal's findings in part. It acknowledged that Sisvel had a dominant position on the market, but there was no abuse of this dominant position by Sisvel. Furthermore, it found that Haier had indeed infringed Sisvel's SEPs as it had not made sufficient efforts to obtain a licence, emphasizing that implementers must state their willingness to obtain licences in a reasonable time period after receiving the infringement notice.

\subsection{Sisvel v Wiko ${ }^{22}$}

In 2016, Sisvel filed a lawsuit against Wiko regarding its European Patent (EP 1119 997), after offering Wiko a complete FRAND licence on its patent pool "Mobile Communication Program" (MCP). Wiko responded by filing a nullity action against the SEP in suit before the German Federal Patent Court. Sisvel requested that the ongoing infringement proceedings be stayed until the German Federal Patent Court rendered its decision on the validity of the SEP. In October 2018, the German Federal Patent Court upheld the SEP to a limited extent. Since the SEP was going to expire in October 2019, Wiko did not appeal the decision. Sisvel again offered Wiko a new licence which was adapted according to the restrictions. In November 2018, the Mannheim Regional Court moved on with the infringement proceedings and ruled in favor of Sisvel. The judges found that Wiko had been too hesitant in the negotiations of the second licence offer. In July 2019, after the end of the oral hearings, Wiko made a new counteroffer to Sisvel. However, Wiko did not increase the amount of security deposited after its first counteroffer made in November 2016. The court granted an injunction against Wiko and ordered the removal and destruction of all the products form the market which infringed Sisvel's SEP. Furthermore, the court ordered Wiko to provide Sisvel with all the necessary information required for the calculation of damages.

\subsection{Continental v Nokia ${ }^{23}$}

Nokia holds a portfolio of SEPs relevant to the connectivity of cars, which Daimler incorporates in its cars though Telematics Control Units. Continental, headquartered

\footnotetext{
${ }^{22}$ Sisvel v. Wiko, Mannheim District Court, 4 September 2019, Case-No. 7 O 115/16.

${ }^{23}$ Continental v Nokia, Munich Court of Appeal, 2019, Case No. 6 U 5042/19.
} 
in Germany, is a supplier of Daimler. Two companies of the Continental group, i.e. the German Continental Automotive GmbH and the Continental Automotive Hungary Kft joined the German infringement proceedings as interveners. In May 2019, the USA subsidiary of Continental, Continental Automotive Systems Inc. (Continental USA), filed a suit against Nokia and others for antitrust violations before the United States District Court for the Northern District of California (US Court). Continental USA, in June 2019, filed for an anti-suit injunction, requesting the US court to prohibit Nokia from prosecuting the German infringement proceedings. In July 2019, Nokia filed for a preliminary injunction before the District Court of Munich (District Court). Nokia made a request to the District Court asking to order Continental USA to withdraw the anti-suit injunction it filed in the US Court. The District Court granted Nokia's preliminary injunction request against Continental USA. ${ }^{24}$ In late July 2019, the District Court issued an injunction against Continental Germany as well. ${ }^{25}$ However, Continental Germany appealed the decision. In September 2019, Continental USA withdrew the anti-suit injunction. However, in October 2019, Continental USA filed for a Temporary Restraining Order against Nokia before the US court, requesting the court to prevent Nokia from maintaining its patents in Germany against companies of the continental group and their clients. Nevertheless, the motion was rejected. The Higher District Court of Munich (Appeal Court) dismissed the appeal of Continental Germany and confirmed the injunction granted by the District court in late July 2019.

\subsection{Conversant v Daimler ${ }^{26}$}

In August 2019, Conversant filed a suit against Daimler at the Regional Court Munich I for infringement of four of its SEPs (EP 2934 050, EP 3300 421, EP 3267 722 and EP 1797 659), all of which protect mobile communication standards such as LTE. In October 2018, Conversant joined the Avanci licensing platform and in December 2018, Conversant made an offer for a bilateral worldwide licence to Daimler and provided all the necessary information about its SEP portfolio. In February 2019, Daimler showed willingness to sign a FRAND licence and subsequently started negotiations for a pool licence with Avanci. However, no agreement could be made. Initially, Conversant did not include a claim for injunctive relief. However, in January 2020, Conversant raised claims for injunctive relief, and recall and destruction of all the infringing products. In April 2020, Daimler made a counteroffer to Conversant, based on the value of the Telematic Control Unit, which is the component enabling LTE-connectivity in cars. In June 2020, Conversant made an offer to Daimler which was not accepted. The Court ruled in favor of Conversant and granted the injunction against Daimler.

\footnotetext{
${ }^{24}$ Nokia v. Continental, District Court of Munich, Order dated 11 July 2019, Case-No. 21 O 3999/19.

${ }^{25}$ Nokia v. Continental, District Court of Munich, Order dated 30 July 2019, Case-No. 21 O 9512/19.

${ }^{26}$ Conversant v. Daimler, District Court of Munich, 30 October 2020, Case-No. 21 O 11384/19.
} 


\section{France}

\subsection{Wiko v Sisvel ${ }^{27}$}

Sisvel performs the function of an intermediary between implementers seeking access to high-level technology and patent owners willing to grant licences to their portfolio. Sisvel sent letters to numerous French distributors and customers of Wiko, alleging that Wiko had infringed its patent essential to the LTE standard. Wiko retaliated by suing Sisvel before the Tribunal de Commerce de Marseille, claiming that Sisvel had practiced unfair competition by sending the above mentioned letters. The court cited paragraphs 61 and 63 of the CJEU's 2015 judgment in Huawei $v$ ZTE, in which the court sets forth the conditions that a SEP owner seeking an injunction against the alleged infringer must satisfy in order to avoid liability under Art. 102 TFEU (prohibition of abuse of dominant position). ${ }^{28}$ Furthermore, the court noted that Sisvel was complying with the FRAND measures set by the CJEU in Huawei $v$ ZTE, making a proper offer for a licence and informing third parties about SEP rights. The court therefore concluded that letters sent by Sisvel constitute a FRAND offer and do not amount to an act of unfair competition.

\subsection{Conversant v LG ${ }^{29}$}

In 2011, Conversant acquired a patent portfolio from Nokia which included more than two thousand patents declared essential to $2 \mathrm{G}, 3 \mathrm{G}$ and $4 \mathrm{G}$ standards. Both the parties entered negotiations to license the portfolio. Yet, the negotiations failed. In September 2014, Conversant filed a suit against LG before the Tribunal de Grande Instance seeking damages, claiming that LG had infringed its patents declared essential to the 2G, 3G and 4G standards (EP 1031192 B 1, EP 881786 BI, EP 950330 BI, EP 978210 Blet and EP 1548973 BI). It further requested for determination of a FRAND royalty rate. ${ }^{30}$ In 2015 , the court rejected Conversant's claims, as no evidence of infringement had been made. ${ }^{31}$ On appeal, Conversant asserted two of the original five patents (EP 950330 BI, EP 978210 Blet). The Court of Appeal of Paris upheld the first instance decision, finding the patents in suit not essential to the standards. ${ }^{32}$

\subsection{IPCom v Lenovo ${ }^{33}$}

In 2017, IPCom acquired a patent portfolio from Bosch, covering certain aspects of $2 \mathrm{G}, 3 \mathrm{G}$ and $4 \mathrm{G}$ telecommunication technology. One of the patents is EP 1841268

\footnotetext{
${ }^{27}$ Wiko v Sisvel, Tribunal de Commerce de Marseille, 2016, Case No. RG 2016F01637.

${ }^{28}$ Cotter [10].

${ }^{29}$ Conversant v. LG, Court of Appeal of Paris, 16 April 2019.

${ }^{30}$ Dhenne [11].

${ }^{31}$ Core Wireless v LG, District Court (Tribunal de Grande Instance) of Paris, judgment dated 17 April 2015, Case No. 14/14124.

${ }^{32}$ Conversant v LG, Court of Appeal of Paris, judgement dated 16 April 2019, Case No. 15/17037, p. 15-24.

${ }^{33}$ IPCom v. Lenovo, Court of Appeal of Paris - RG 19/21426, March 2020 - Case No. 14/2020.
} 
B2 (EP 268), declared essential to the 3G standard. In September 2018, IPCom made a licensing offer to Lenovo. However, Lenovo did not respond even after a formal letter was sent again by IPCom in March 2019. Then, after receiving the formal letter from IPCom, Lenovo initiated proceedings against IPCom in the US. Lenovo claimed that IPCom's offer was not on FRAND terms and therefore, sought to have a global FRAND rate set by the US District Court for the Northern District of California (US District Court) for the patent portfolio of IPCom. In July 2019, IPCom filed an infringement suit against Lenovo before the High Court in London, seeking an injunction against the products which infringed its patents. In September 2019, Lenovo filed an anti-suit injunction before the US District Court in order to prevent IPCom from continuing with the UK proceedings and filing any other lawsuits against Lenovo or seek any anti-anti suit injunction before any foreign court. In October 2019, IPCom responded by seeking a preliminary injunction for patent infringement in the Tribunal de Grande Instance of Paris and filing an anti-anti-suit injunction in France and England, prohibiting Lenovo from pursuing its anti-suit injunction in the US. Both the French and English courts granted the anti-anti-suit injunction. In March 2020, the French Court of Appeal upheld the French injunction - however, it overruled the order of the first instance court forbidding Lenovo from pursuing any other anti-suit motions.

\section{The Netherlands}

\subsection{Archos v Philips ${ }^{34}$}

In June 2014 Philips brought its UMTS and LTE patent portfolio and licence program to the attention of Archos by letter. In the letter, Philips notified Archos that they were infringing Philips' SEPs (EP1440525, EP1685659 and EP1623511) by marketing products incorporating the UMTS and LTE standards, and further wrote about a possible FRAND licence. However, despite having various negotiations, no agreement could be reached. In October 2015, Philips filed a suit before the Hague District Court for infringement of their SEPs, seeking an injunction against Archos to prevent it from using Philips' SEPs. Archos argued that Philips' offer was not on FRAND terms and therefore, Philips' action for an injunction was abuse of dominance. The court rejected the Archos' claim regarding abuse of dominance by Philips. It was held that instead of Philips, it was Archos that prevented a final agreement from being made. Further, the court took into account that (i) Archos showed unwillingness to start proper negotiations as they had stated that Philips would need to sue them in order to get higher royalties; and (ii) Archos' low profits did not necessarily mean that the offer made by Philips was not on FRAND terms.

${ }^{34}$ Archos S.A. v. Koninklijke Philips N.V., NL, The Hague District Court, 2017, ECLI:NL:RBDHA: 2017:1025. 


\subsection{Koninklijke Philips N.V. v Asustek Computers Incorporation ${ }^{35}$}

In 2013, Philips notified Asus of its portfolio of 3G-UMTS and 4G-LTE wireless telecommunications standards and proposed a licensing agreement. In 2015, after all the attempts to negotiate failed, Philips filed an infringement suit against Asus based on its SEP European Patent 1623511 for a 'Communication System' (EP 511) in various European jurisdictions. Philips declared the EP 511 patent essential to the 3G-UMTS and 4G-LTE standards. The High Court in London delivered a preliminary verdict, upholding the validity of the EP 511 patent. In the Netherlands, Philips filed a suit before the District Court of The Hague, seeking an injunction against Asus. However, the court rejected Philips' request. ${ }^{36}$ Philips further appealed before the Court of Appeal of The Hague. The Court of Appeal upheld the validity and essentiality of the EP 511 and rejected Asus' FRAND defense based on Art. 102 TFEU. Furthermore, it granted Philips the injunction against Asus. ${ }^{37}$

\subsection{Philips v Wiko ${ }^{38}$}

In October 2013, Philips notified Wiko claiming that its products infringed Philips' patents essential to the UMTS and LTE mobile telecommunication standards and proposed a possible FRAND licensing agreement. However, Wiko did not respond. In October 2015, Philips brought an action against Wiko, after which in August 2016, Wiko made a counteroffer. The District Court of Mannheim accepted Wiko's FRAND defense and rejected Philips' action. In April 2019, the Court of Appeal of The Hague upheld the validity of the SEPs and found Wiko responsible for the infringement. Wiko claimed that Philips' initial offer was not on FRAND terms and therefore, Philips was abusing its dominant position by not making an offer based on FRAND terms and further refusing to negotiate with Wiko on the basis of Wiko's counteroffer during the proceedings. The Court of Appeal dismissed Wiko's claims regarding abuse of dominance by Philips and granted Philips' request for injunctive relief, destruction and recall of all the products which infringed its SEPs.

\subsection{Sisvel v Xiaomi ${ }^{39}$}

Sisvel's patent EP 2139272 (EP 272) protects a system for attaching mobile equipment to a wireless network. Xiaomi argued that the LTE standard does not include all elements of Sisvel's patent claims and therefore, the patent is not essential. ${ }^{40} \mathrm{EP}$ 272 was found to be non-essential by the District Court of The Hague. As a result,

\footnotetext{
${ }^{35}$ Koninklijke Philips N.V. v. Asustek Computers INC, District Court of the Hague, 2017, Case No. C 09 512839 /HA ZA 16-712.

$36_{\text {ibid. }}$

${ }^{37}$ Koninklijke Philips N.V. v. Asustek Computers INC, The Hague Court of Appeal, 2019, Case No. 200.221.250/01.

${ }^{38}$ Koninklijke Philips N.V. v. Wiko SAS, The Hague Court of Appeal, 2019, Case no. 200.219.487/01.

${ }^{39}$ Sisvel v Xiaomi, The Hague Court of Appeal, 2020, Case No. C/09/573969/ KG ZA 19-462.

${ }^{40}$ Sisvel v. Xiaomi, The Hague District Court, judgment dated 5 November 2020, Case ID: ECLI:NL:RBDHA:2020:11108; see also, Richter [12].
} 
Sisvel's infringement suit against Xiaomi was rejected. In March 2020, the Court of Appeal of The Hague held that a preliminary injunction was inappropriate in FRAND proceedings. ${ }^{41}$ The court adopted the approach of balancing interests. It took into account various factors, including the fact that the damages which Sisvel seeks to avert are restricted to the Netherlands and only concern a single patent which is about to expire (in October 2020); since Sisvel is a non-practicing entity - the court further pointed out - the damages which it seeks to prevent through a preliminary injunction constitutes a loss of income and not a loss of market exclusivity. ${ }^{42}$ This is significant as it does not happen often that Dutch courts take the non-practicing entity status of a corporation into account. ${ }^{43}$

\section{Italy}

\subsection{Samsung v Apple ${ }^{44}$}

In October 2011, Samsung brought an infringement suit against Apple before the Court of Milan, claiming that Apple manufactured iPhone 4s incorporating its SEP related to the telecommunications system 3G (the Italian portion of EP 1188269). Both parties had unsuccessfully conducted negotiations with a view to enter into a licence agreement, leading Samsung to request an injunction against Apple. The Court noted that Apple was a willing licensee as it had put efforts in negotiations with Samsung in order to obtain a licence. Therefore, the Court rejected Samsung's request for an injunction. It stated that "an injunction sought on the ground of a Standard Essential Patent cannot be granted if the party against whom it is requested has shown through serious negotiations the intention to obtain a licence on that patent". ${ }^{45}$

\subsection{Ical, Italvideo International and Cardmania Multimedia v Rovi Guides and United Video Properties ${ }^{46}$}

Ical Spa, Italvideo International Srl and Cardmania filed a suit against the US companies, Rovi Guides and United Video Properties (defendants) before the Court of Milan, requesting to invalidate the Italian part of the defendants' patent EP 0755417, which covered the "Electronic Programming Guides System"-a standard technology that provides television users with updated menus that display scheduling information for current and upcoming broadcast programming. United Video owned the patent while Rovi Guides licensed it. Alternatively, Ical, Cardmania and Italvideo

\footnotetext{
${ }^{41}$ Ibid, at 34 .

${ }^{42}$ Broekstra [13].

43 ibid.

${ }^{44}$ Samsung Electronic Co. Ltd and Samsung Electronic Italia Spa vs Apple Inc., Apple Italia Srl, Apple Retail Italia Srl and Apple Sales International, Court of Milan, January 2012.

${ }^{45}$ Bonadio, McDonagh, Chierichetti [14].

${ }^{46}$ Ical Spa, Italvideo International Srl and Cardmania Multimedia Srl vs Rovi Guides Inc., United Video Properties Inc., Court of Milan, July 2015.
} 
asked the court to decide upon the FRAND royalty. Furthermore, they argued that the defendants had abused their dominant position by refusing to grant a licence on FRAND terms. Moreover, they claimed that royalties asked by the defendants were significantly higher than the rest of the market. Following this, Ical, Italvideo and Cardmania asked the court to declare non-infringement of the Italian part of patent EP 0755417.

Rovi Guides and United Video Properties then started proceedings against Ical, Italvideo and Cardmania in the Court of Milan, asking the court to issue an injunction and seizure orders. In 2015 the court issued the final decision. It granted the orders since Ical, Italvideo and Cardmania had started exploiting the patented technology without properly obtaining a licence. However, by the end of the proceedings, the court declared the Italian part of the patent void and not essential to the standard, as the patent did not meet the requirements needed to categorize the patent as standard essential. Since the patent was found to be non-essential, the court rejected the claims of abuse of dominance against Rovi Guides and United Video.

\subsection{Sisvel and Braü Verwaltungsgesellschaft vs. Toshiba ${ }^{47}$}

For four years Sisvel and Toshiba Europe negotiated a potential licence agreement over the European patent EP 595790 ("EP790”) owned by the German company Braü and licensed to Sisvel. These negotiations failed in 2010. That year, a container with 700 Toshiba devices was seized at the La Spezia port by the Italian customs authority. The seizure was later extended to other products stored in a Toshiba warehouse.

In 2012 Sisvel introduced proceedings on the merits against Toshiba before the Court of Milan, asking the Court to declare that the defendant infringed the Italian portion of EP790. According to Sisvel, the devices manufactured and imported by Toshiba (TVs and video recorders) infringed the claims of EP790, which covered features regulated by the ETSI standard EN 300294 entitled "Television systems; 625-line Television Wide Screen Signalling".

The court-appointed expert however concluded that EP790's priority was not correctly claimed and, therefore, the patent as filed was not novel. Sisvel and Braü filed a reformulated version of the claims, but the court-appointed expert held that, in the new wording, EP790 did not coincide with the ETSI standard. In any case, Sisvel could not bring enough evidence to prove that Toshiba's TVs infringed the patent. The Court of Milan sided with the experts and rejected Sisvel's action. In April 2020 the Court of Appeal of Milan confirmed the first instance decision. ${ }^{48}$

\subsection{Philips v Advanced Digital Broadcast (ADB) and ZAP 49}

In 2015 Philips sued ADB and ZAP before the Court of Milan claiming that the latter companies had infringed the Italian portions of EP 745307 (“EP307”) and EP 754

\footnotetext{
${ }^{47}$ Sisvel S.p.A., Braü Verwaltungsgesellschaft mbH vs. Toshiba Europe GmbH, Court of Milan, 31 October 2017.

${ }^{48}$ Sisvel S.p.A., Braü Verwaltungsgesellschaft mbH vs. Toshiba Europe GmbH, Court of Appeal of Milan, 14 April 2020.

${ }^{49}$ Koninklijke Philips N.V. vs. ADB - Advanced Digital Broadcast S.A., ADB Italia S.r.1.,ZAP S.p.a., Court of Milan, 16 April 2020.
} 
393 ("EP393") by producing and distributing the TV decoder "Set Top Box". The defendants counterclaimed for invalidity and argued that EP307 and EP393 could not be considered SEPs.

Philips had formally declared to ETSI that EP307 and EP393 were essential patents to the DVB subtitling standard (EN 300 743). Philips also held an intense FRAND licensing campaign through VIS Licensing Corporation, but contacts with ADB never led to an agreement.

The Court declared both patents valid and infringed. As to the essentiality of EP307 and EP393, the Court found it did not have sufficient information to decide and sent back the case to the court-appointed expert, stressing that the overall compensation of damages would be affected by the qualification of the patents at stake as SEPs or not. There is currently no published decision on the essentiality prong of this case.

\subsection{Sisvel v ZTE Italy and Europhoto trading ${ }^{50}$}

In December 2015, Sisvel started preliminary injunction proceedings before the Court of Turin, enforcing its European patent EP 1264504 ("EP504") which was declared essential to the UMTS standard. EP504 was part of the "Sisvel Wireless Patents" portfolio, allegedly covering technical features of the GSM, GPRS, UMTS and LTE standards. The defendants were ZTE Italy, the Italian branch of smartphone manufacturer ZTE Corporation, and Europhoto, a reseller of ZTE devices based in Turin.

In December 2012, Sisvel informed ZTE Corporation - the defendant's parent company - about its SEPs portfolio, arguing that its patents were implemented in ZTE devices and asking ZTE Corporation to enter into a licence on FRAND terms. The companies negotiated for almost three years, but did not reach an agreement. Early in the negotiations, in 2013, Sisvel and ZTE Corporation entered into a nondisclosure agreement ("Agreement"), wherein Sisvel also agreed not to enforce its patent rights against ZTE Corporation and its affiliates for three years.

That said, the Court of Turin rejected Sisvel's preliminary injunction request. Referring to the principles established by the CJEU in Huawei, the Court noted that Sisvel had negotiated the potential FRAND licence only with ZTE Corporation, the parent company. However, Sisvel had not informed ZTE Italy, the subsidiary, of the alleged patent infringement, of its intention to bring preliminary injunction proceedings, nor of the technical features covered by the patent claims that were considered essential to the telecommunications standards. It followed that, according to the Court, Sisvel did not meet the Huawei obligations vis-à-vis ZTE Italy and therefore could not be granted an injunction.

The Court of Turin added that, in any case, the covenant-not-to-sue included in the Agreement specifically prevented Sisvel from filing an infringement action against ZTE Corporation and its affiliates, including ZTE Italy. Although Sisvel had sent a letter to ZTE Corporation to unilaterally terminate the Agreement before the beginning of the proceedings, this termination was ineffective under a reasonable interpretation of the Agreement. Hence, the Court held, Sisvel could not bring an action

${ }^{50}$ Sisvel International S.A. 
concerning the "Sisvel Wireless Patents" portfolio against any of the ZTE companies until 3 September 2016 (i.e. three years after the Agreement was signed).

Finally, the Court issued a preliminary injunction against the other defendant, Europhoto. While Europhoto argued that they had stopped selling ZTE phones, the Court stressed that this was not sufficient to exclude the risk of a future infringement.

In the appeal proceedings, the Court of Turin - sitting in a Panel of three Judges - confirmed the first instance decision. The Court found once again that Sisvel had not validly terminated the Agreement. Therefore it was prevented from filing an action against ZTE based on the "Sisvel Wireless Patents" portfolio. The Court also noted that this interpretation of the Agreement was valid under both US law (i.e. the governing law) and Italian law.

Finally, at the discussion hearing before the Panel in the appeal proceedings Sisvel argued that one could also consider that EP504 was not essential to the UMTS standard and, therefore, Sisvel would not be bound to the Huawei principles on prior notice nor to the agreements signed in relation to such notice, such as NDAs. The Court of Turin firmly dismissed this argument stressing that Sisvel itself had declared that EP504 was an essential patent, and that it was ready to grant a licence on it at FRAND terms.

It is also worth recalling that the EP504 patent has been litigated by Sisvel also in Germany against Haier. The case went up to the German Supreme Federal Court, which confirmed that EP504 was valid and infringed on 24 November 2020.

\section{Conclusion}

As mentioned, standardisation has become key, especially in the ICT and IoT. And we have seen that SEPs are frequently litigated in Europe. In the seminal case Huawei $v$ ZTE the CJEU established important guidelines to balance the interests of SEP owners seeking an injunction and those of implementers.

Most decisions made by courts in the jurisdictions analysed in this paper align with the CJEU's guidelines and further show willingness to award injunctive relief to SEP owners where the necessary requirements are met. Some of them have also highlighted the importance of relying on solid essentiality checks. This was the case of the Court of Milan in Ical $v$ Rovi, for example. This is a relevant point. Indeed, accessing accurate information on the scale of exposure to SEPs is extremely important to users of standards, especially small and medium-sized enterprises which have little experience of licensing practices and enter the relevant markets looking for connectivity.

UK case law does raise peculiar issues. The approach of the UK Supreme Court in Unwired Planet v Huawei on global licensing, followed by the High Court in $\mathrm{Op}$ tis $v$ Apple, is particularly delicate. On the one hand, it can be argued that it offers a pragmatic solution which promotes cost efficiency and commercial certainty; and that reflects industry practice, as opposed to the hypothetical and abstract considerations. ${ }^{51}$ The decision is thus likely to strengthen the position of the UK as an attractive

${ }^{51}$ Trust et al. [15]; see also Osborne Clarke Insights [16]. 
jurisdiction for SEP holders, given that "a global licence may be secured without the requirement for infringement proceedings in a large number of jurisdictions". 52

On the other hand, such global licence approach has attracted criticism for its alleged extra-territorial impact. Indeed, commentators have gone as far as arguing that the decision constitutes a "impermissible jurisdictional overreach" and that the Supreme Court has adopted a "colonial" or "imperialist" approach. ${ }^{53}$ Although the UK injunction itself does not cover jurisdictions outside the UK, it nonetheless gives the patent owner significant leverage in the negotiations over a global licence. This in practice - if not in law - affects patents valid in other territories, including key jurisdictions in the EU such as France, Germany, the Netherlands and Italy. It is not difficult to see the controversy in the fact that a SEP implementer might end up paying high global royalties as a result of a UK judgment on a UK patent because of the indirect impact on foreign patents valid in other jurisdictions (which cannot be disputed in the UK).

Also, in an intriguing move, in Unwired Planet $v$ Huawei the UK Supreme Court suggested that rather than country-by-country enforcement, a world tribunal would be best placed to resolve SEP disputes. More specifically, it noted:

- "Those policies ... do not provide for any international tribunal or forum to determine the terms of such licences. Absent such a tribunal it falls to national courts, before which the infringement of a national patent is asserted, to determine the terms of a FRAND licence. The participants in the relevant industry ... can devise methods by which the terms of a FRAND licence may be settled, either by amending the terms of the policies of the relevant SSOs to provide for an international tribunal or by identifying respected national IP courts or tribunals to which they agree to refer such a determination." 54

At present, no such tribunal is being contemplated at the international or European level, but it is an interesting idea that may gain ground if country-by-country litigation becomes unworkable. Time will tell.

Open Access This article is licensed under a Creative Commons Attribution 4.0 International License, which permits use, sharing, adaptation, distribution and reproduction in any medium or format, as long as you give appropriate credit to the original author(s) and the source, provide a link to the Creative Commons licence, and indicate if changes were made. The images or other third party material in this article are included in the article's Creative Commons licence, unless indicated otherwise in a credit line to the material. If material is not included in the article's Creative Commons licence and your intended use is not permitted by statutory regulation or exceeds the permitted use, you will need to obtain permission directly from the copyright holder. To view a copy of this licence, visit http://creativecommons.org/licenses/by/ $4.0 \%$.

\section{References}

1. Bharadwaj, A., Verma, D.: Failure is not falling down but refusing to get up: implication of Huawei/ZTE framework (CJEU 2015) in Europe. In: The John Marshall Review of Intellectual Property Law, vol. 17 , p. 326 (2018)

\footnotetext{
${ }^{52}$ Kempner, Ward [17].

${ }^{53}$ Trust et al. [15].

${ }^{54}$ Unwired Planet v Huawei [2020] UKSC 37, para 90.
} 
2. Bonadio, E., McDonagh, L.: Car wars: how Nokia could find itself at centre of EU investigation over technology patents (2020). Available at https://theconversation.com/car-wars-how-nokia-could-finditself-at-centre-of-eu-investigation-over-technology-patents-129643

3. Bonadio, E., McDonagh, L.: Networked technologies in the car industry, standard essential patents and refusal to license: the CJEU will soon shed light in Nokia v Daimler (2020). Available at https:// blogs.city.ac.uk/citylawforum/2020/12/18/networked-technologies

4. Klos, M.: Nokia and Daimler settle all global litigation in connected cars dispute (2021). Available at https://www.juve-patent.com/news-and-stories/cases/nokia-and-daimler-settle-all-global-litigationin-connected-cars-dispute/

5. Heard, C., Morgan, G., Wong, E.: TQ Delta v ZyXEL - Court of Appeal cancels the RAND trial as ZyXEL no longer a 'willing licensee' (2019). Available at https://www.cms-lawnow.com/ ealerts/2019/07/tq-delta-v-zyxel-court-of-appeal-cancels-the-rand-trial-as-zyxel-no-longer-a-willinglicensee

6. Bristows: Review of Patent Cases in the English Courts in 2019 (2020). Available at https://www. bristows.com/app/uploads/2020/03/Bristows_PROTY-final-digital.pdf

7. Sherliker, T.: Court of Appeal cancels RAND trial in ZyXEL v TQ Delta (2019). Available at https:// ipkitten.blogspot.com/2019/07/court-of-appeal-cancels-rand-trial-in.html

8. Raynor, M.: Technical primers where infringement / essentiality / equivalents case involves complex technology - Mitsubishi \& Sisvel v OnePlus \& Xiaomi [2021] EWHC 1639 (Pat) (2021). Available at http://patentblog.kluweriplaw.com/2021/06/21/technical-primers-where-infringement-essentialityequivalents-case-involves-complex-technology-mitsubishi-sisvel-v-oneplus-xiaomi-2021-ewhc1639-pat/

9. Lambert, J.: Patents - Mitsubishi Electric Corporation v Oneplus Technology (2021). Available at https://nipclaw.blogspot.com/2021/07/patents-mitsubishi-electric-corporation.html

10. Cotter, T.: French Court Rejects Unfair Competition Claim Based on Patentee's Compliance with Huawei v. ZTE (2016). Available at: http://comparativepatentremedies.blogspot.com/2016/11/frenchcourt-rejects-unfair-competition.html

11. Dhenne, M.: Conversant v LG: What about FRAND in France? Eur. Intellect. Prop. Rev. 585 (2019)

12. Richter, K.: District Court of the Hague declares Sisvel patent non-essential (2020). Available at https://www.juve-patent.com/news-and-stories/cases/district-court-of-the-hague-declares-sisvelpatent-non-essential/

13. Broekstra, R.: NL - Sisvel v. Xiaomi - PI based on SEP denied (2020). Available at http://patentblog. kluweriplaw.com/2020/03/30/nl-sisvel-v-xiaomi-pi-based-on-sep-denied/

14. Bonadio, E., McDonagh, L., Chierichetti, F.: Standard Essential Patents in Italy: a review of the existing case law (2021). Available at http://patentblog.kluweriplaw.com/2021/04/21/standard-essentialpatents-in-italy-a-review-of-the-existing-case-law/

15. Trust, B., et al.: Future Facing Disputes - Technology licensing after Unwired Planet - Jurisdictional overreach by the UK Supreme Court or the future of global licensing disputes? (2021). Available at https://cms.law/en/gbr/publication/future-facing-disputes-technology-licensing-after-unwiredplanet-jurisdictional-overreach-by-the-uk-supreme-court-or-the-future-of-global-licen

16. Osborne Clarke Insights: Unwired Planet unpacked: are English courts the de facto global tribunal for SEP licensing disputes? (2020). Available at https://www.osborneclarke.com/insights/unwiredplanet-unpacked-english-courts-de-facto-global-tribunal-sep-licensing-disputes/

17. Kempner, R., Ward, G.: UK: Unwired Planet v Huawei - Supreme Court Rules on Global FRAND Licensing Powers of UK Courts (2020). Available at https://www.mondaq.com/uk/patent/980246/ unwired-planet-v-huawei-supreme-court-rules-on-global-frand-licensing-powers-of-uk-courts

Publisher's Note Springer Nature remains neutral with regard to jurisdictional claims in published maps and institutional affiliations. 